\title{
Peningkatan Kompetensi Berbahasa Inggris Warga Belajar PKBM Ar-Rohmah dengan Metode Integrated Skill
}

\author{
Diyah Fitri Wulandari*, Destary Praptawati, Riana Permatasari \\ Sastra Inggris, Universitas Islam Sultan Agung, Semarang, Indonesia \\ *Corresponding Author \\ Email: diyahfitri@unissula.ac.id \\ Received: \\ 06 May 2021 \\ Revised: \\ 05 November 2021 \\ Accepted: \\ 17 November 2021 \\ Published: \\ 27 November 2021
}

\begin{abstract}
Abstrak
Salah satu tujuan utama mempelajari bahasa Inggris di era globalisasi saat ini adalah kemampuan dalam percakapan bahasa Inggris. Namun, kemampuan percakapan bahasa Inggris masih dianggap sebagai salah satu keterampilan yang sulit dilakukan bagi banyak orang, tidak terkecuali warga belajar di PKBM. Banyak warga belajar menghadapi beberapa kesulitan ketika mereka ingin berkomunikasi dengan bahasa Inggris, meskipun mereka telah mempelajari bahasa Inggris bertahun-tahun lamanya. Sebagai solusi untuk memberikan motivasi warga belajar untuk dapat berkomunikasi dengan bahasa Inggris yaitu dengan menyediakan media pengajaran yang menarik melalui metode pembelajaran yang efektif. Pada pengabdian ini metode yang digunakan adalah dengan menggunakan Integrated Skill. Hasil dan manfaat dari kegiatan pengabdian ini salah satunya adalah memberikan pengetahuan tentang bahasa inggris dan melatih keterampilan berbahasa inggris khusunya bahasa inggris aktif bagi warga belajar.
\end{abstract}

Kata Kunci: Pusat Kegiatan Belajar Masyarakat; Warga Belajar; Integrated Skill

\begin{abstract}
One of the main reasons of learning English in this globalization era is to improve the ability in speaking and communicating in English. However, the ability to communicate and to speak in English perfectly is still regarded as a difficult skill to master by some people, one of them is the students of PKBM Ar Rohmah. Most students face some difficulties when they want to communicate in English, although they have learned English language for many years they do not have sufficient capability on it. As a solution to motivate the students in order to be able to communicate in English is by providing the interesting suitable learning media and using a effective learning method. In the community service, the method used is Integrated skill. The result and advantages of this community service is to give knowledge about English language and to improve the English skill for the students.
\end{abstract}

Keywords: Learning Center; Integrated skill 


\section{PENDAHULUAN}

Globalisasi dan perkembangan teknologi mengharuskan setiap orang untuk dapat berkomunikasi dengan dunia dalam berbagai bahasa. Salah satunya adalah bahasa Inggris (Juriana, 2018). Bahasa Inggris merupakan bahasa internasional dan paling banyak digunakan di dunia (Zulaikah, 2019). Dengan memiliki kemampuan bahasa Inggris yang baik, dapat dikatakan seseorang telah mempunyai bekal dasar untuk bersaing dengan jutaan orang di dunia (Ariwibowo et al., 2020). Karena dengan kecakapan berbahasa seseorang dapat mengemukakan ide dan gagasan sehingga dapat dijangkau oleh audience yang lebih luas (Sholihah, 2020).

Mempelajari bahasa merupakan hal yang mudah untuk dilakukan. Niat dan kesungguhan untuk belajar merupakan syarat utama dalam memulai belajar bahasa, dalam hal ini bahasa Inggris. Ketekunan dalam belajar juga menjadi faktor pendukung keberhasilan seseorang dalam mempelajari Bahasa Inggris (Tamrin \& Yanti, 2019). Selain itu disiplin, hal ini juga sangat membantu penguasaan bahasa Inggris. Hal ini juga yang terjadi di PKBM Ar-Rohmah.

PKBM Ar-Rohmah merupakan lembaga pendidikan yang berlokasi di Desa Kembang Arum Mranggen Kabupaten Demak. PKBM ini merupakan lembaga penyelenggara kejar paket, yaitu kejar paket B dan C. Banyak sekali warga belajar yang mengikuti kegiatan pendidikan di PKBM ini. Warga belajar tersebut berasal dari berbagai daerah di sekitar Semarang dan Demak dan dari berbagai latar belakang profesi. Ada yang bekerja sebagai karyawan pabrik, karyawan Jasa Ekspedisi Internasional, Pedagang, dan Petani. Warga belajar di PKBM Ar-Rohmah ini tidak hanya belajar tentang akademik saja, tetapi mereka juga dibekali dan difasilitasi dengan berbagai macam program keahlian salah satunya kemampuan berbahasa Inggris. Atas inisiasi pengelola PKBM, maka diadakan program pelatihan bahasa inggris yang dapat bermanfaat bagi warga belajar.

Namun dalam pelaksanaannya, kegiatan pelatihan bahasa inggris yang dilakukan di PKBM Ar-Rohmah belum sesuai dengan kebutuhan warga belajar, yaitu peningkatan kecakapan berbicara, membaca, mendengarkan dan menulis (Ariyani, 2018). Oleh karena itu diperlukan metode yang tepat untuk mencapai tujuan tersebut. Integrated Skill adalah salah satu metode yang memandang empat keterampilan berbahasa yaitu listening (mendengarkan), speaking (berbicara), reading (membaca) dan writing (menulis), sebagai suatu kesatuan dan tidak terpisah (Brown, 2001).

Metode integrated skill juga didesain untuk menjadikan siswa lebih aktif. Disamping itu siswa juga metode integrated skill ini dapat membantu siswa memecahkan masalah yang dihadapi, dalam hal ini terkait dengan keterampilan berbicara (Pardede, 2020). Sebelum berlatih berbicara bahasa inggris, terlebih dahulu siswa diajarkan membaca, mendengarkan dan menulis. Sehingga dalam berbicara siswa sudah memiliki lebih banyak kosakata dan pengetahuan tata bahasa. Hal ini juga dapat meningkatkan retensi (daya ingat) siswa sehingga menjadikan siswa lebih mudah mempelajari bahasa baru, dalam hal ini bahasa Inggris 


\section{Permasalahan Mitra}

Kegiatan belajar yang dilakukan PKBM Ar-Rohmah umumnya dalam bidang akademik dan bersifat teoritis saja, diantaranya Pancasila, Matematika, bahasa Indonesia dan lainlain. Peningkatan kompetensi kebahsaan khususnya Bahasa asing dalam hal ini Bahasa Inggris memang sudah diterapkan di banyak lembaga pendidikan, begitu juga yang terjadi di PKBM Ar Rohmah.

Kurangnya kecakapan dalam berbahasa inggris menjadikan seseorang lebih percaya diri dan meningkatkan kompetensinya, sehingga jika orang tersebut telah mnyelesaikan pendidikannya, dia dapat bersaing dan memanfaatkan keterampilan yang dimilikinya di dunia kerja.

\section{Solusi dan Target Luaran}

Kegiatan ini dilaksanakan dalam bentuk pelatihan dan pendampingan bagi warga belajar PKBM dan untuk membekali mereka dengan keterampilan berbahasa Inggris aktif sehingga dapat meningkatkan komptensinya untuk bersaing.

Kegiatan ini dilaksanakan dengan melibatkan peserta secara aktif untuk praktik menggunakan Bahasa Inggris secara langsung dengan menerapkan 4 keterampilan dasar berbahasa yaitu speaking, listening, reading dan writing, yang terintegrasi sehingga dapat membantu peserta menguasai Bahasa Inggris dengan cepat karena dilakuakan dengan pembiasaan. Tema yang diangkat pada setiap pertemuan dalam kegiatan pembelajaran disesuaikan dengan materi atau pokok bahasan bersifat umum dan sederhana, misalnya tentang kegiatan sehari-hari, menjelaskan objek, atau pokok bahasan yang bertema islami seperti sejarah Nabi Muhammad pertama kali mendapatkan wahyu, kisah Nabi Muhammad Hijrah ke Madinah dan lain-lain.

Hal ini diharapakan para peserta, yaitu warga belajar PKBM Ar-Rohmah dapat dengan mudah dan terbiasa untuk paling tidak sedikit demi sedikit menggunakan Bahasa inggris. Sehingga tujuan awal kegiatan ini, yaitu meningkatkan kemampuan Bahasa Inggris santri dapat terpenuhi.

Target luaran kegiatan pengabdian masyarakat ini adalah sebagai berikut:

a. Memberikan pengetahuan tentang pentingnya menguasai bahasa asing khususnya bahasa inggris bagi warga belajar.

b. Meningkatkan kemampuan berbahasa inggris warga belajar PKBM Ar Rohmah

\section{METODE PELAKSANAAN}

Kegiatan pengabdian kepada masyarakat di PKBM Ar-Rohmah ini dilaksanakan dengan beberapa tahapan, yaitu:

\section{Tahapan pelaksanaan}

Pada tahap awal ini, tim pengabdian melakukan observasi di PKM Ar-rohmah dan kemudian menemui pengelola PKBM Ar-Rohmah untuk mendapatkan informasi yang berkaitan dengan situasi kegiatan belajar mengajar di PKBM Ar-Rohmah, khususnya 
tentang kebutuhan warga belajar terhadap beberapa keterampilan pendukung, salah satunya adalah keterampilan berbahasa Inggris.

Selanjutnya, tim pengabdian masyrakat membuat solusi alternatif untuk menyelesaikan masalah tersebut. Tim pengabdian mengumpulkan beberapa literatur diantaranya buku-buku referensi, modul, video dan alat peraga lain yang dapat digunakan untuk kegiatan pengabdian. Selain itu, tim pengabdian juga membuat beberapa media pembelajaran yang menarik sehingga dapat meningkatkan antusiasme warga belajar dalam mengikuti kegiatan pelatihan.

\section{Proses Implementasi}

Kegiatan pengabdian ini dilakukan dalam bentuk pelatihan bahasa Inggris. Kegiatan pelatihan ini, terbagi menjadi beberapa bentuk Aktivitas, diantaranya pembelajaran konvensional (tim pengabdian menjelaskan materi), drilling untuk melatih listening dan speaking, membaca dan membuat kalimat serta praktik berbicara di depan kelas. Dengan kata lain, dalam setiap pertemuan diajarkan 4 skill kebahasaan yaitu, reading, listening, writing, dan speaking. Seluruh skill tersebut diajarkan secara bergantian sehingga dapat meningkatakan penguasaan dan kemahiran bahasa inggris warga belajar.

\section{Evaluasi}

Setelah proses implementasi, tim peneliti menijau kembali keefektifan penggunaan metode integrated skill dalam kegiatan pelatihan ini. Proses evaluasi ini dilaksanakan dengan melihat kelemahan dan kekurangan yang ada selama kegiatan pelatihan berlangsung (Magdalena et al., 2020). Saran dan feedback dari peserta menjadi bahan evaluasi utama bagi tim pengabdian masyarakat ini.

\section{HASIL DAN PEMBAHASAN}

Kegiatan pengabdian masyarakat ini berlangsung dalam bentuk pelatihan dan pendampingan. Pelatihan secara luring mulai dilaksanakan pada hari minggu tanggal 10 Januari 2021, dan selanjutnya pelatihan dilakukan pada hari minggu mulai pukul 09.00 12 WIB. Kegiatan pelatihan ini bertempat di kampus Ar-Rohmah Mranggen. Hampir semua warga belajar paket $C$ hadir dalam kegiatan ini. Bahkan ada beberapa peserta yang merupakan warga belajar paket B juga mengikuti kegiatan ini, sehingga total ada 40 peserta yang hadir mengikuti pelatihan ini. 


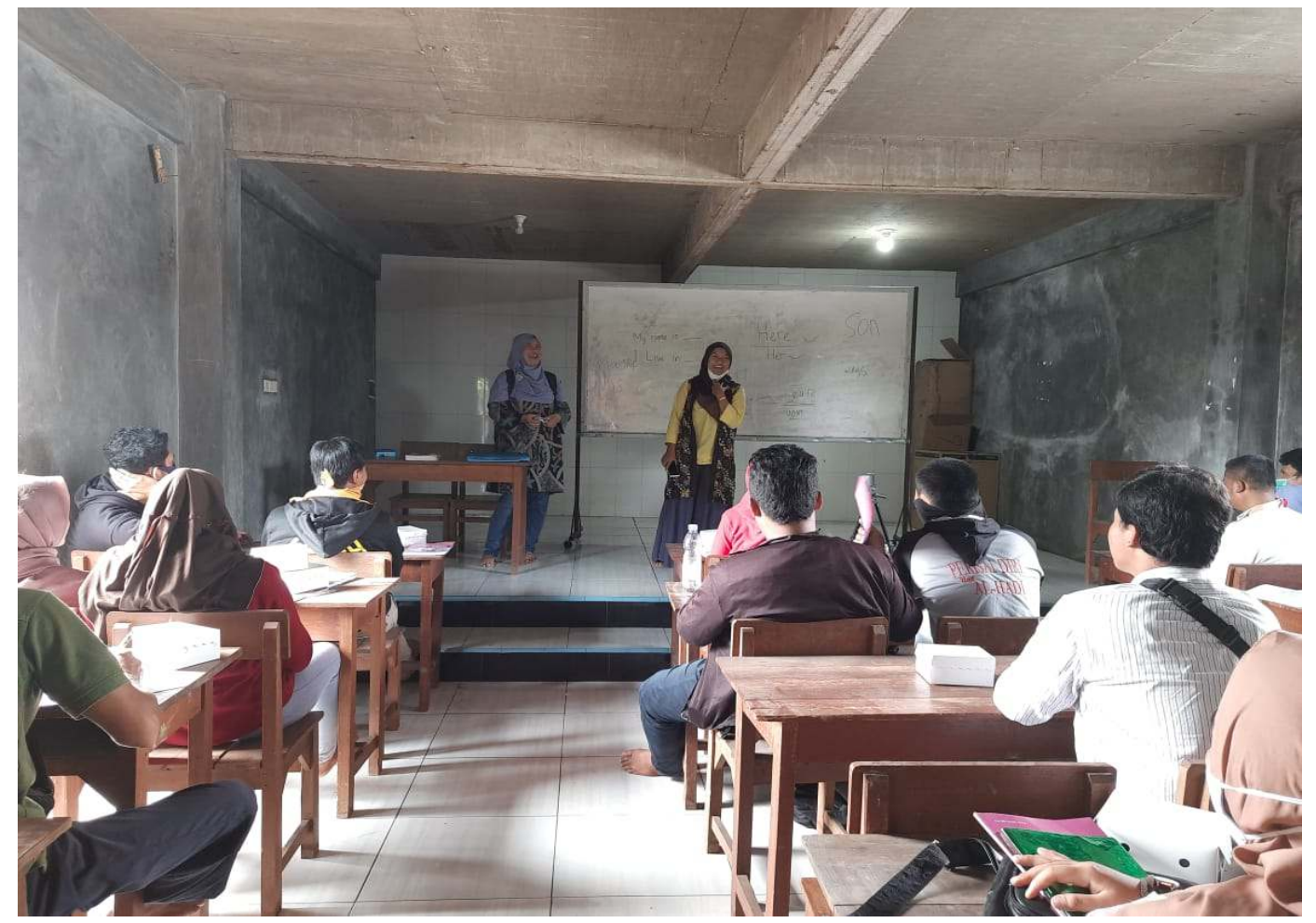

Gambar 1. Tim PKM Unissula sedang menyampaikan materi

Aktivitas pertama yang dilakukan dalam kegiatan pelatihan ini adalah pemberian materi tentang membaca teks berbahasa Inggris. Pada kegiatan ini, peserta diajari tentang perbendaharaan kosakata bahasa inggris dengan membaca teks dan menerjemahkan kosakata baru yang para peserta belum mengetahui artinya dalam bahasa Indonesia. Para peserta diminta untuk membaca teks tersebut satu per satu. Kegiatan membaca ini membatu melatih peserta dalam mengucapkan kata dan kalimat dalam bahasa Inggris.

Setelah belajar membaca dan menguasai beberapa kosakata dalam bahasa Inggris, para peserta dilatih untuk mengucapkan kata-kata tersebut dengan baik dan benar serta mirip dengan native speaker. Praktik pengucapan ini berlangsung cukup lama namun tetap terasa menyenangkan karena semua peserta antusias dan saling sahut-menyahut membetulkan jika ada peserta yang kurang tepat dalam mengucapkan sebuah kata. Aktivitas ini sangat membantu peserta dalam praktik speaking nantinya. 


\section{Indonesian Journal of Community Services}

Volume 3, No. 2, November 2021

http://jurnal.unissula.ac.id/index.php/ijocs

DOI: http://dx.doi.org/10.30659/ijocs.3.2.153-160

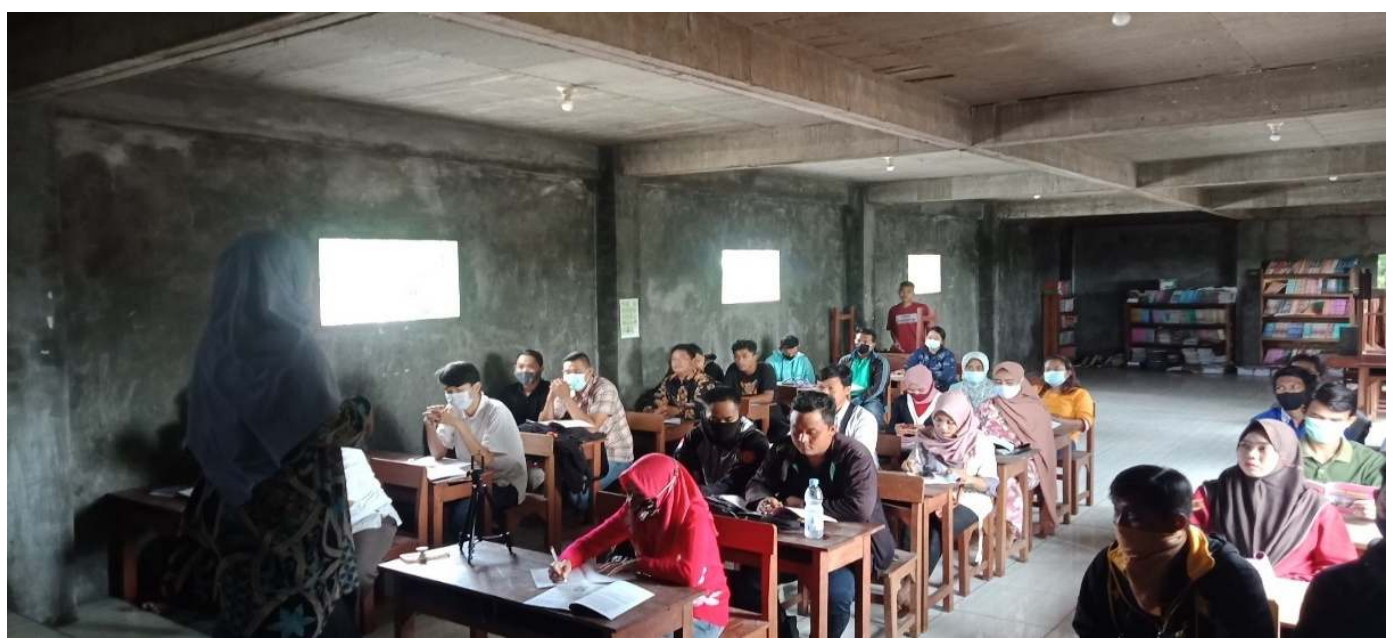

Gambar 2. Tim PKM Unissula sedang melatih pronunciation peserta

Selanjutnya, para peserta diminta untuk membuat kalimat sederhana dalam bahasa Inggris dengan terlebih dahulu tim pengabdian menjelaskan tentang menulis kalimat dan pola kalimat. Perbendaharaan kosakata baru yang didapatkan dari Aktivitas sebelumnya dapat membatu peserta untuk melakukan Aktivitas kedua ini. Para peserta membuat kalimat dengan didampingi oleh tim pengabdian. Tim pengabdian masyarakat berkeliling kelas untuk membantu peserta yang mengalami kesulitan dalam merangkai kata menjadi sebuah kalimat.

Di akhir sesi menulis, peserta diwajibkan membaca kalimat masing-masing secara bergiliran dengan sukarela. Kemudian tim pengabdian memberikan feedback dan koreksi untuk setiap peserta. Dalam kegiatan ini, peserta sangat antusias, bahkan ada satu pesertayang membuat kalimat dua kali lebih banyak dari yang diminta.

Kegiatan berikutnya adalah praktik berbicara. Pada kesempatan ini, tim pengabdian melakukan review materi yang sudah dipelajari pada sesi sebelumnya, yaitu pada sesi reading dan writing. Kemudian peserta diminta untuk berbicara menjelaskan " $M y$ hometown" atau kotaku.

Pada setiap sesi speaking, peserta awalnya merasa sangat sulit untuk bisa membuat kalimat dan kemudian mengucapkan kalimat tersebut secara lantang. Sebagian peserta awalnya merasa kurang percaya diri untuk presentasi di depan teman-temannya.Namun, dengan bimbingan dan bantuan tim pengabdi, para peserta menjadi semangat dan antusias untuk praktik berbicara.

Dari Aktivitas kegiatan pelatihan in, metode integrated skill tepat diterapkan karena memiliki sejumlah kelebihan sebagai berikut:

a. Peserta menjadi aktif dalam kegiatan belajar

b. Metode ini cocok untuk meningkatkan empat keterampilan kebahasaan, yaitu reading, writing, listening dan speaking.

c. Suasana pembelajaran menjadi lebih menarik, dan menyenangkan serta tidak tegang.

d. Tutor dalam hal ini pengandi lebih bersemangat dan aktif. 
Hal yang paling penting dalam pelaksanaan kegiatan pengabdian masyarakat ini adalah capaian hasil kegiatan yang diterapkan. Soft skill, dalam hal ini kemampuan berbahasa asing, salah satunya adalah bahasa Inggris. Setelah kegiatan ini, diharapkan kemampuan dan kecakapan berbahasa inggris peserta, yaitu warga belajar Ar Rohmah dapat meningkat karena penguasaan bahasa Inggris dapat meningkatkan daya saing masyarakat di era teknologi.

Tanggapan peserta pelatihan dalam kesempatan ini adalah warga belajar PKBM ArRohmah cukup antusias, hal ini terbukti dari peneriaan mereka terhadap kelas yang kami laksanakan. Para peserta menyambut dengan wajah ceria dan dengan senang hati mengikuti seluruh rangkaian kegiatan pengabdian masyarakat ini. Kegiatan Pengabdian masyarakat ini merupakan kegiatan lanjutan dari program oengabdian masyarakat sebelumnya. Kegiatan yang pernah dilakukan adalah pelatihan bahasa Inggris dasar.

Dalam pelaksanaan sebuah kegiatan, akan selalu ada kendala yang dihadapi, meskipun kendala tersebut kecil dan terbilang tidak berarti. Kegiatan ini dilaksanakan di tengan pandemic covid 19, maka kegiatan ini dibatasi oleh waktu dsehingga dirasa kurang optimal karena interaksi langsung yang terjadi di dalam kelas terbilang kurang. Penerapan protocol kesehatan khusunya physical distancing atau jaga jarak dan penggunaan masker membuat tim pengabdian harus sering mengulang-ulang apa yang dikatakan, karena suara tidak terdengar dengan jelas.

\section{KESIMPULAN}

Berdasarkan pembahasan yang telah disampaikan pada paparan di atas, dapat ditarik kesimpulan bahwa kegiatan pengabdian kepada masyarakat ini, yaitu pelatihan bahasa Inggris bagi warga belajar PKBM Ar Rohmah sangat bermanfaat dan menarik minat para peserta. Kegiatan ini telah memberikan kesempatan kepada warga belajar untuk meningkatkan keterampilan berbahasa Inggris aktif dengan melatih empat skill kebahasaan yaitu reading, writing, listening dan speaking. Seluruh rangkaian kegiatan pengabdian dapat berjalan dengan baik dan bermanfaat seluruh warga belajar serta tim pengabdian masyarakat.

\section{UCAPAN TERIMA KASIH}

Syukur kepada Allah SWT yang telah memberikan kemudahan dalam pelaksanaan kegiatan Pengabdian Masyarakat ini. Terimakasih kepada pihak-pihak yang telah membantu terselenggaranya kegiatan engabdian masyarakat ini: Universitas Islam Sultan Agung melalui Lembaga Penelitian dan Pengabdian Masyarakat dengan programprogram dan bantuan dana yang memudahkan kami melaksanakan kegiatan pengabdian masyarakat ini, rekan-rekan di Fakultas Bahasa dan Ilmu Komunikasi yang turut mendukung kegiatan ini, pengelola PKBM Ar-Rohmah yang menyambut baik kegiatan ini dan para warga belajar PKBM Ar-Rohmah yang berperan sangat penting untukkeberhasilan kegiatan ini. 


\section{DAFTAR PUSTAKA}

Brown, H. D. (2001). Teaching by Principles: An Interactive Approach to Language Pedagogy. Second Edition. Addison Wesley Longman

Chamot, A.\& Robbins, J. 1999. The Learning Strategies Handbook. Longman

Ariwibowo, S., Yuliastuti, A., \& Pujimahanani, C. (2020). PELATIHAN BAHASA INGGRIS SANTRI PONDOK PESANTREN BISMAR AL-MUSTAQIM SURABAYA DENGAN PENDEKATAN Abstrak. 05(02), 91-96.

Ariyani, E. (2018). BERORIENTASI KERJA BAGI PESERTA KEJAR PAKET C DI KELURAHAN TANJUNG KARANG KOTA MATARAM - NUSA. 1(1), 13-22.

Juriana, J. (2018). Pentingnya Penggunaan Bahasa Inggris dalam Komunikasi Dakwah pada Era Global. Mawa'Izh: Jurnal Dakwah Dan Pengembangan Sosial Kemanusiaan, 8(2), 241-258. https://doi.org/10.32923/maw.v8i2.773

Magdalena, I., Fauzi, H. N., Putri, R., \& Tangerang, U. M. (2020). Pentingnya Evaluasi Dalam Pembelajaran Dan Akibat Memanipulasinya. Pendidikan Dan Sains - Stitpn, 2 ,

244-257. https://ejournal.stitpn.ac.id/index.php/bintang/article/download/986/680/

Pardede, P. (2020). Integrating the 4Cs into EFL Integrated Skills Learning. Journal of English Teaching, 6(March), 71-85. https://doi.org/10.33541/jet.v6i1.190

Sholihah, R. A. (2020). Praktik Pembelajaran Keterampilan Berbicara Di Masa Pandemi Covid-19. NATURALISTIC: Jurnal Kajian Penelitian Pendidikan Dan Pembelajaran, 5(1), 705-717. https://doi.org/10.35568/naturalistic.v5i1.977

Tamrin, A. F., \& Yanti, Y. (2019). Peningkatan keterampilan bahasa Inggris masyarakat pegunungan di Desa Betao Kabupaten Sidrap. Transformasi: Jurnal Pengabdian Masyarakat, 15(2), 61-72. https://doi.org/10.20414/transformasi.v15i2.1673

Zulaikah, Z. (2019). Upaya Meningkatkan Kemampuan Berbicara Bahasa Inggris dalam Percakapan Sehari-Hari dengan Metode VAK (Visualization, Auditory, Kinestetic) bagi Para Santri Pondok Pesantren Nurul Huda 2 Tanah Merah. Jurnal Indonesia Mengabdi, 1(1), 6-10. https://doi.org/10.30599/jimi.v1i1.420 